\title{
MEASUREMENT OF AVALANCHE SPEEDS AND FORCES: INSTRUMENTATION AND PRELIMINARY RESULTS OF THE RYGGFONN PROJECT
}

\author{
by \\ H. NOREM \\ Norwegian Geotechnical Institute, P.O. Box 40 - Taasen, N0801 Oslo 8, Norway
}

T. KVISTER $\varrho Y$

AME, P.O. Box 83, N1391 Horten, Norway

\section{B. D. EVENSEN}

Norwegian Water Resources and Electricity Board, P.O. Box 5191 - Majorstua, N0302 Oslo 3, Norway

\section{ABSTRACT}

The Ryggfonn project is a full scale experiment carried out to investigate the impact of avalanches on structures and the effects of a retaining dam in the avalanche path. The vertical drop of the avalanche path is $910 \mathrm{~m}$ and the volume of the avalanches is 20 . $100000 \mathrm{~m}^{3}$

The experimental set-up consists of: a $15 \mathrm{~m}$ high retaining dam in the runout zone, instrumented with strain gauges on a $6.5 \mathrm{~m}$ steel mast and a load cell on a $1.0 \mathrm{~m}$ mast, plus a $4.5 \mathrm{~m}$ high concrete structure instrumented with three $0.72 \mathrm{~m}^{2}$ load cells, and three transmission line conductors strung across the avalanche path. The recorded analogue signals are digitized using Pulse-Code-Modulation (PCM) and recorded on a magnetic tape recorder.

Up to May 1984, speed data from five avalanches have been analysed, and impact pressures have been recorded from three of them. The maximum speeds vary between $38 \mathrm{~m} / \mathrm{s}$ and $60 \mathrm{~m} / \mathrm{s}$. The maximum recorded impact pressure was $541 \mathrm{kPa}$, and averaged $220 \mathrm{kPa}$ over a 15 second interval. A maximum pressure of 83 $\mathrm{kPa}$ was measured on a load cell buried under snow at the base of the concrete structure.

\section{INTRODUCTION}

The Ryggfonn project, named after the avalanche site Ryggfonn, is a full scale experiment carried out to investigate avalanche flow and impact pressures of avalanches.

The main purposes of the project are:

- To study the use of a retaining dam to collect snow and reduce the runout distance.

- To measure and evaluate the forces on structures in the avalanche track.

- To measure and evaluate the tensile forces in transmission conductors crossing the avalanche track above the ground.

The experiments were carried out near NGI's field station in Grasdalen, Western Norway. The avalanches in Ryggfonn start at $1530 \mathrm{~m}$ a.s.l. and the mean slope of the avalanche path is $28^{\circ}$. Usually $2-3$ avalanches per year come down to the valley bottom. The size and maximum speeds of the avalanches vary between 20 . $100000 \mathrm{~m}^{3}$ and $30-60 \mathrm{~m} / \mathrm{s}$ respectively.

\section{INSTALLATIONS AND INSTRUMENTATION}

Since 1981 the following installations and instrumentations have been carried out (Figure 1). More detailed information is given by Kvister $\phi y$ (1983) and Lied (1984).

\section{The retaining dam}

A $100 \mathrm{~m}$ long retaining dam made of approximately $26000 \mathrm{~m}^{3}$ earth-fill has been constructed. The dam stands $11 \mathrm{~m}$ above the original terrain and rises $15 \mathrm{~m}$ from top to bottom on the avalanche side. On top of the dam, a $6.5 \mathrm{~m}$ high and $0.3 \mathrm{~m}$ wide steel mast is instrumented with six strain gauges to measure deflections in the mast. Four gauges are mounted $2.4 \mathrm{~m}$ above the top of the dam for providing axial and moment stresses, and two $3.8 \mathrm{~m}$ above the top for providing moment stresses. The mast should withstand an equivalent uniformly distributed static load of $40 \mathrm{kPa}$.

In addition a $0.16 \mathrm{~m}$ diameter load cell is mounted at the northern end $1.0 \mathrm{~m}$ above the top of the dam The load cell records both impact pressures and the time that snow passes the top of the dam.

The concrete structure

Above the dam, $230 \mathrm{~m}$ up the avalanche path, a $4.5 \mathrm{~m}$ high and $0.6 \mathrm{~m}$ wide concrete structure has been constructed. The impact pressures of the avalanches are measured by three load cells, each $0.6 \mathrm{~m} \times 1.2 \mathrm{~m}$ Because the load cells cover the whole front area, and the size of each cell at least is of the size of the snowmasses hitting them, the recorded pressures are considered to give realistic values for design purposes. The nominal full range of the sensors is $1000 \mathrm{kPa}$. On top of the structure a geophone vibration sensor is mounted with the sensitive axis aligned vertically.

\section{The transmission line conductors}

At the same elevation as the concrete structure two $16 \mathrm{~m}$ steel masts have been installed, on either side of the avalanche path. Three $162 \mathrm{~m}$ transmission lines have been strung between the masts, 8,12 and $16 \mathrm{~m}$ above the ground. Both ends of the cables are instrumented with a load cell. To prevent the effect of torque and shear forces, the load cells are mounted using tongueand yoke-shackles as well as a rotation device. The full nominal range of the sensors is $227 \mathrm{kN}$ tension.

\section{The data recording system}

The data are transmitted by armoured multipair cables to the recording instruments and placed in a hut $300 \mathrm{~m}$ south of the retaining dam. The maximum cable length is $700 \mathrm{~m}$. The recording system consists of bridge DC-amplifiers with automatic null-balance and automatic adjustment of bridge excitation voltage using the remote sensing signals, and 5-pole lowpass filters to improve signal-to-noise ratio and to eliminate aliasing errors. Analog multiplexers multiplex 32-channels into a 


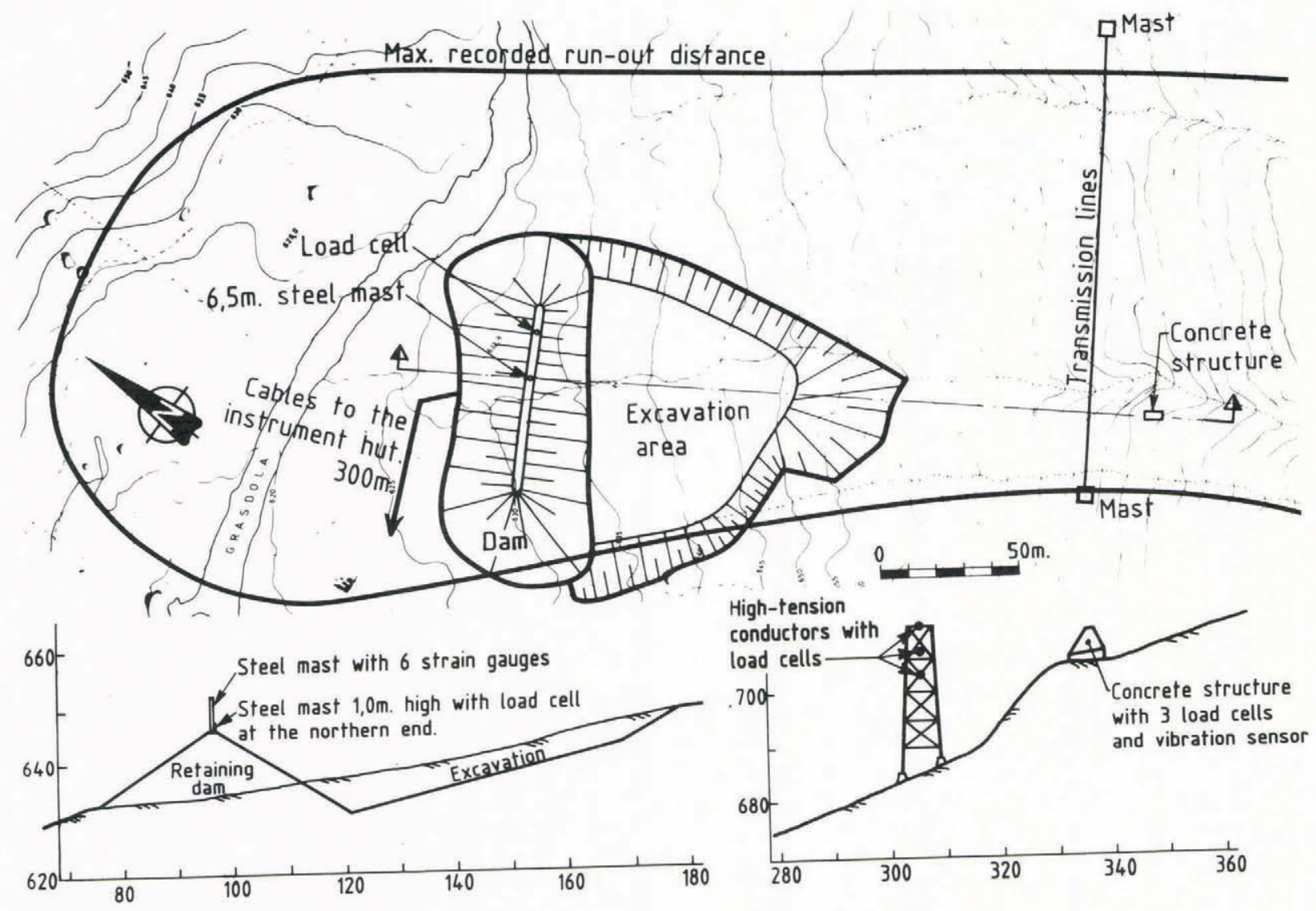

Fig.1. The experiment site and cross-section profile of dam, masts and concrete structure.

2-channel system and a PCM-modulator which digitize the analog signals to 12-bit (4096 parts) accuracy, and put the digital signals on a serial bit-stream. A small magnetic tape-recorder is used to record the serial digital data.

The sampling rate is 333.33 samples per sec. for each of the 32 premultiplexed channels. The filters are set to a cut-off of $75 \mathrm{~Hz}$. Recorded data are read into a PRIME-750 computer and filed on a directed structure together with calibration data. Computation of engineering values, plotting of data, statistical work as well as Fourier transformations to check frequency distribution of signal energy are possible.

The sensor and recording system is protected against accumulation of static charges and high potentials from lightning using Faraday's cage principle, overvoltage protecting diodes and proper grounding.

Full symmetry for all measuring bridges was attempted, to eliminate thermoelectrical effects and resistance changes due to temperature changes and mechanical stresses.

\section{OPERATION}

The system can be operated manually for recording artificially triggered avalanches. All measuring channels are null-balanced a short time before recording, and the triggering of avalanches is done by radio-controlled detonation of preplanted charges. The front speeds of the avalanches are evaluated by photographs, and snow properties and volume of snow deposits are measured.

For naturally released avalanches, the recording system is triggered by positive detection of snow avalanche pressure on the upper load cell. Data from 2.4 seconds before detection are saved by using semiconductor memory. However, there are no photographs available for evaluating the avalanche speeds for naturally triggered avalanches.
RESULTS

Avalanche speeds

Up to May 1984 we have obtained speeds data from 6 avalanches in Ryggfonn, two of them from an earlier investigation before the construction of the dam (Tøndel 1977). Snow conditions varied from dry snow $(25$ February 1975) to wet snow in the whole path (23 April 1983) and also dry snow in the upper part of the path and wet snow in the rest. All avalanches except one had a common front for both the powdered snow and dense flow down to $700 \mathrm{~m}$ a.s.l. where there are simulataneous recordings on both the stucture and the transmission lines. Somewhere between this point and the stopping position, the powder snow overrides the dense flow; thus there is insufficient information about the avalanche velocity of the dense flow in the runout zone. For the sixth avalanche, there was a time difference between the powder snow and the dense flow of as much as $20 \mathrm{~s}$ at the concrete structure.

The relationship for the five analyzed avalanches between time used and horizontal distance travelled is shown in Figure 2. Maximum velocities vary between 38 $\mathrm{m} / \mathrm{s}$ and $60 \mathrm{~m} . / \mathrm{s}$ (see also Bakkehøi and others 1983) and the runout distance for four of these varies by less than $100 \mathrm{~m}$. The $\mathrm{fifth}$ avalanche passed the valley bottom by approximately $50 \mathrm{~m}$.

The only equation used today for estimating avalanche velocities is the Voellmy-Perla equation (Voellmy 1955, Perla 1980), which is based on a friction parameter, $\mu$, and a turbulence parameter called by Perla $M / D$. The time-distance relationship is computed for four sets of $\mu(0.2$ and 0.3$)$ and $M / D(900 \mathrm{~m}$ and $450 \mathrm{~m})$ by the method described by Bakkehøi and others (1981); Figure 2 .

The model, with only 2 parameters, does not provide a very good fit for the time taken, runout distance and maximum velocity. For some of the 


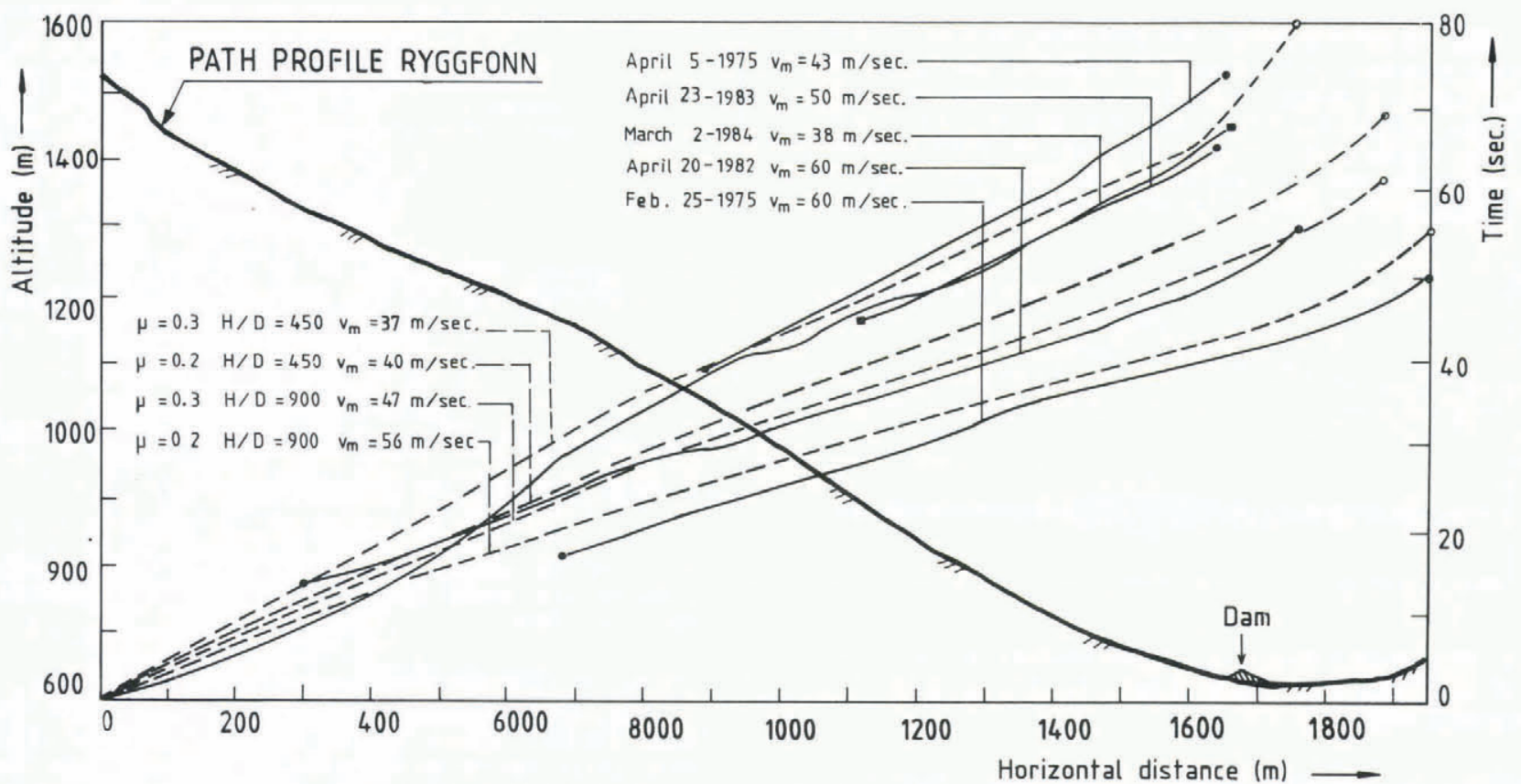

Fig.2. The relationship between time and distance travelled for five avalanches, and computed values of the Voellmy-Perla equation.

avalanches it can be explained that these parameters vary along the path because of variations in the snow conditions. The highest inaccuracies have been found in the runout zone, where the observed avalanches have a shorter runout distance and a more distinct retardation than the model indicates. Future analyses will be concentrated on a better physical understanding of what kinds of flow actually occur in avalanches. It may then be possible to benefit from previous experiments on such kinds of flow.

\section{Recorded impact pressures on the concrete structure}

Impact pressures have been recorded from four avalanches. Maximum pressures occurred in an avalanche of 23 April 1983. That avalanche consisted of wet snow; the velocity at the structure was $30 \mathrm{~m} / \mathrm{s}$, and the size of the avalanche was estimated to be $50000 \mathrm{~m}^{3}$. The density of the snowmasses was measured to $450 \mathrm{~kg} / \mathrm{m}^{3}$ and up to $650 \mathrm{~kg} / \mathrm{m}^{3}$ in the compacted snow in front of the dam. The masses passed the structure for a period of $50 \mathrm{sec}$. Figure 3 shows the snow profile around the structure before the avalanche was triggered, and the recorded maximum pressures; Figure 4 shows a selected part of the recordings.

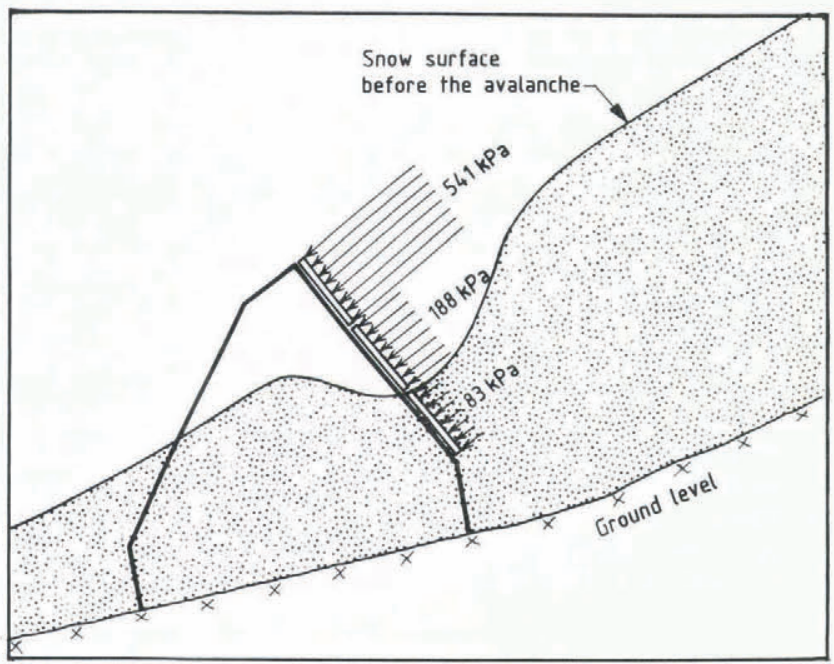

Fig.3. Snow surface before the avalanche and peak pressures on the concrete structure, 23 April 1983.
The peak pressure, $541 \mathrm{kPa}$, was recorded on the upper load cell. Maximum pressure averaged over $15 \mathrm{sec}$. was $220 \mathrm{kPa}$. The time difference from the first signal to the peak value varied between $1.5 \mathrm{sec}$. (very small avalanche) to $15 \mathrm{sec}$. for the four analysed avalanches. In the literature the pressure, $p$, is usually estimated as $\mathrm{p}=\mathrm{k} \cdot \rho \cdot \mathrm{v}^{2}$, with $\mathrm{k}$ varying from 0.5 for constructions submerged in the flow to 2.0 for peak pressures on small load cells. With an assumed density of $p=450$ $\mathrm{kg} / \mathrm{m}^{3}$ and recorded front speed of $\mathrm{v}=30 \mathrm{~m} / \mathrm{s}$, the back-calculated values for $k$ are respectively 0.54 and 1.33. The ratio between peak and average pressures is 2.46 , comparable with the ratio reported by Schaerer (1980) for load cells with an area of $0.645 \mathrm{dm}^{2}$.

The maximum recorded pressure on the lower, completely buried load cell was $83 \mathrm{kPa}$ or $15 \%$ of the peak pressure on the upper load cell. The pressure on the lower load cell increased gradually with only small peak values, and the maximum pressure was recorded at almost the same time on all load cells (Figure 4). It is however still unclear whether impact pressure is an effect of flowing snow masses passing the load cell, or shear stresses transferred through the original snow cover.
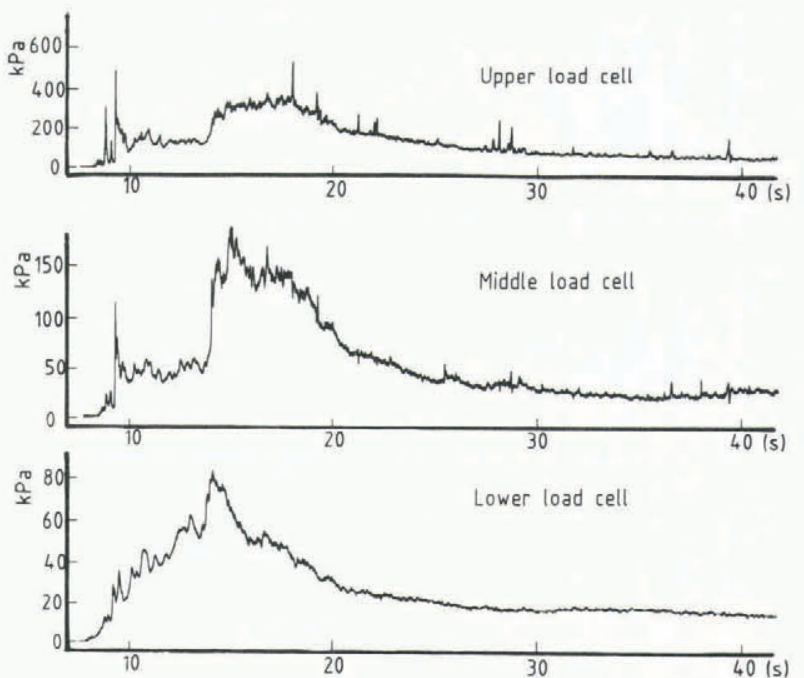

Fig.4. Impact pressures on the concrete structure, 23 April 1983. 
The output signal of the geophone on top of the concrete structure is very well correlated to the recorded impact pressure (Figure 5). There are no recordings of vibrations before the dense flow hits the structure, and the peak values occur at the same time for both sensors. The measurements indicate that geophones are suitable for detecting avalanches. The use of geophones is earlier

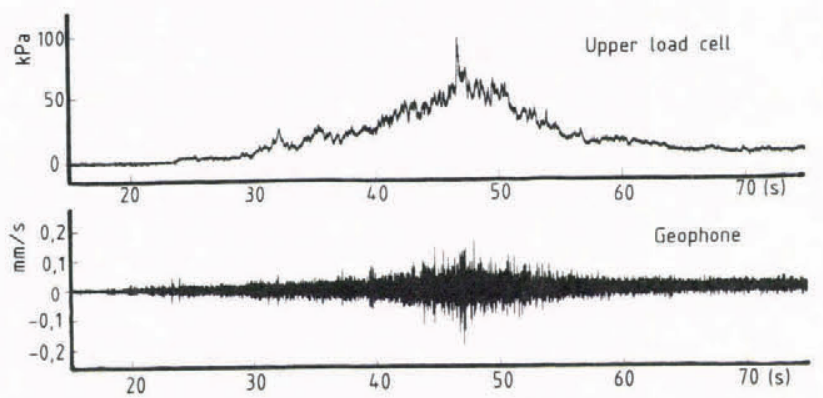

Fig.5. Correlation between the impact pressure on the upper load cell and the output signal of the geophone, 8 December 1983.

described by Schearer (1980) for the measurements of avalanche velocities, and by Norem (1981) for warning of road-users by illuminating red lights when an avalanche has been detected.

\section{Recorded tension in the transmission line conductors}

There are recordings on the transmission lines, 8, 12 and $16 \mathrm{~m}$ above ground from three avalanches. In addition, the avalanche on 10 January 1983 destroyed some strands on the two lowest lines.

The maximum values recorded so far are only $10 \%$ of the expected maximum values. The probable reason is that recordings are only from wet snow avalanches, with widths only about $30 \%$ of the maximum width.

Contrary to the load cells, the transmission lines recorded peak tensions a short time after the first impact (Figure 6). This effect is clearest for the lowest line, with the highest recorded tensions. Peak values for the three lines are respectively $1.3,3.0$ and $18.9 \mathrm{kN}$ for the avalanche of 23 April 1983, and $3.0,4.1$ and $38.9 \mathrm{kN}$ for the avalanche of 2 March 1984 (Figure 7). The preliminary results indicate that the energy is concentrated in the lower part of the powder snow.

From an engineering point of view, the energy distribution related to the height above the surface is important. Unfortunately the program for computing the equivalent static load and natural damping of initial
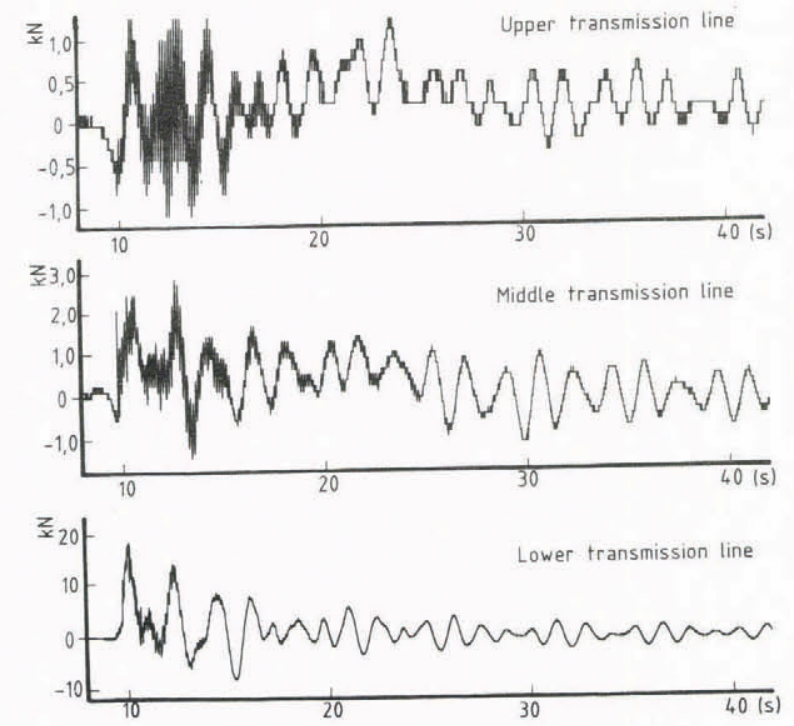

Fig.6. Tensions in the transmission lines, 23 April 1983.

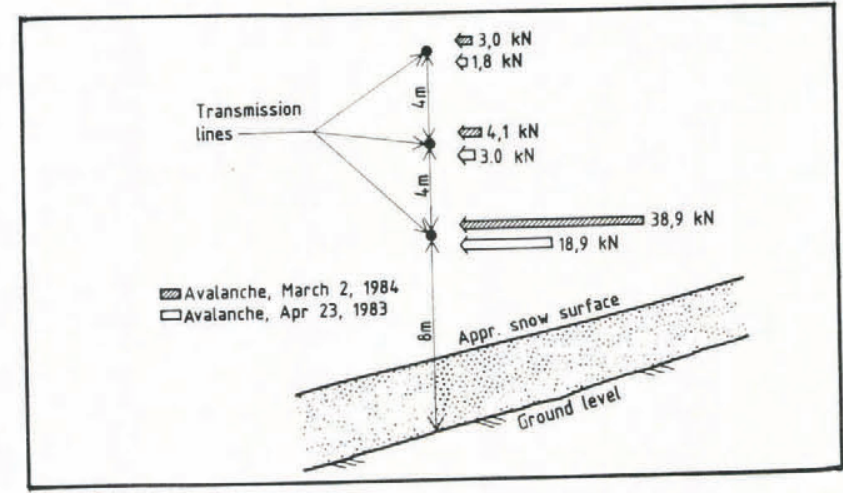

Fig.7. Peak tensions in the transmission lines.

loads is not yet ready, and it is impossible at this stage to compare the impact pressure on the structure and the transmission lines.

\section{FUTURE INVESTIGATIONS}

The Ryggfonn project will be expanded for the winter $1984 / 85$ by a $25 \mathrm{~m}$ high transmission mast located about $100 \mathrm{~m}$ up from the concrete structure. The mast is Y-shaped, with a polyedged cross-section at the lower base. Instrumentation will be based upon strain gauges in two cross sections and an accelerometer on top of the mast.

This will facilitate measurements of impact pressures on whole structures in the avalanche path, and better evaluation of the speed of the dense flow.

\section{ACKNOWLEDGEMENTS}

The project is mainly financed by the Norwegian Geotechnical Institute and the Norwegian Water Resources and Electricity Board. The Norwegian Road Department and the National Fund for Disaster Assistance have also given support to the project. The authors are thankful for their support and interest in the project. The authors also thank the staff at NGI for giving valuable help with both the recording of data and the analysis, with a special thanks to $\mathrm{K}$. Kristensen for doing most of the field work.

\section{REFERENCES}

Bakkehøi S, Cheng T, Domaas, U, Lied K, Perla R, Schieldrop B 1981 On the computation of parameters that model snow avalanche motion. Canadian Geotechnical Journal 18: 121-130

Bakkeh $\phi$ i S, Domaas U, Lied K 1983 Calculation of snow avalanche runout distance. Annals of Glaciology 4: $27-29$

Kvisterøy T 1983 The Ryggfonn project. Description of instrumentation and data registration system. Internal Report, NGI 58120-3 (Unpublished).

Lied K 1984 Earth dams for protection against snow avalanches. Internal Report NGI 58120-4 (Unpublished)

Norem H 1981 Red lights and bells warn the road users of avalanches. Väre Veger 5: 55-56 (in Norwegian)

Perla R, Cheng T T, McClung D M 1980 A two parameter model of snow avalanche motion. Journal of Glaciology 26(94): 197-207

Schaerer P A, Salway A A 1980 Seismic and impact-pressure monitoring of flowing avalanches. Journal of Glaciology 26(94): 179-187

Tøndel I 1977 Protection of roads against avalanches. Meddelelse no 17, Veg- og jernbane-bygging, Norwegian Institute of Technology, Trondheim (in Norwegian)

Voellmy A 1955 Ueber die Zerztörungskraft von Lawinen. Schweizerische Bauzeitung, Zürich, 73(12): 159-162, (15): $212-217$, (17): 246-279, (19): $280-285$ 